\title{
YAC Clone
}

National Cancer Institute

\section{Source}

National Cancer Institute. YAC Clone. NCI Thesaurus. Code C1944.

A yeast artificial chromosome containing a specific DNA fragment. 